\title{
Efficacy and Toxicity of Cisplatin and Capecitabine Combination in the First-Line Treatment of Patients with Advanced Gastric Cancer: A Multicenter Study by the Anatolian Society of Medical Oncology
}

\author{
Aydın CILTAS ${ }^{1}$, Suleyman BUYUKBERBER ${ }^{1}$, Turkan O. TOPCU ${ }^{2}$, Mehmet KUCUKONER ${ }^{3}$, \\ Ummugul UYETURK ${ }^{4}$, Sener CIHAN ${ }^{5}$, Mehmet A. SENDUR ${ }^{6}$, Burcin BUDAKOGLU ${ }^{7}$, \\ Umut KEFELI $^{8}$, Ramazan YILDIZ ${ }^{1}$, Gamze GOKSEL ${ }^{9}$, Veli BERK ${ }^{10}$, Ozan BALAKAN ${ }^{11}$, \\ Berna OKSUZOGLU ${ }^{7}$, Dogan UNCU ${ }^{6}$, Ugur COSKUN ${ }^{1}$, Feyyaz OZDEMIR ${ }^{2}$, Mustafa BENEKLI ${ }^{1}$

\footnotetext{
' Gazi University Faculty of Medicine, Department of Medical Oncology, Ankara

${ }^{2}$ Karadeniz University Faculty of Medicine, Department of Medical Oncology, Trabzon

${ }^{3}$ Dicle University Faculty of Medicine, Department of Medical Oncology, Diyarbakir

${ }^{4}$ Abant Izzet Baysal University Faculty of Medicine, Department of Medical Oncology, Bolu

${ }^{5}$ Okmeydanı Training and Research Hospital, Department of Medical Oncology, Istanbul

${ }^{6}$ Ankara Numune Training and Research Hospital, Department of Medical Oncology, Ankara ${ }^{7}$ Dr. Abdurrahman Yurtaslan Oncology Training and Research Hospital, Department of Medical Oncology, Ankara

${ }^{8}$ Medeniyet University Goztepe Training and Research Hospital, Department of Medical Oncology, Istanbul,

${ }^{9}$ Celal Bayar University Faculty of Medicine, Department of Medical Oncology, Manisa

${ }^{10}$ Erciyes University Faculty of Meedicine, Department of Medical Oncology, Kayseri

${ }^{11}$ Gaziantep University Faculty of Medicine, Gaziantep, Department of Medical Oncology, TURKEY
}

\begin{abstract}
Gastric cancer is an important public health problem which comprises $10 \%$ of all cancers and $12 \%$ of all cancer related deaths all over the world. Because of the differences in patient populations and treatment schemes in various studies, standard practice for advanced stage gastric cancer has not been fully established. The aim of this study was to assess the use of cisplatin and capecitabine combination regimen in real-world clinical practice. Medical records of 76 male and 37 female metastatic gastric cancer patients treated with first-line cisplatin and capecitabine combination between February 2006 and December 2009 were retrospectively analyzed in 11 centers of the Anatolian Society of Medical Oncology. Patients previously treated with chemotherapy were excluded from the analysis. The median age of the patients was 64 years (range, 28-83). Seventy-six (67.2\%) patients were males and 37 (32.7\%) females. Most of the patients were metastatic $(n=85,75.2 \%)$ at the time of initial diagnosis. The most common sites for metastasis were liver (65.9\%), lung (11.3\%), peritoneum (23.8\%) and local recurrence (15.9\%) with multiple metastases in $9.7 \%$ of the patients. The mean follow-up period of all patients was 41 months (range 12-61). Overall response rates was 33.6\%, while disease control rate (DCR) was $72.6 \%$. Median Progression-free survival was 4.7 months $(95 \% \mathrm{Cl} 3.75-6.49)$ and median overall survival was 11.1 months $(95 \% \mathrm{Cl}$ 5.58- 10.98). The most common grade $3-4$ adverse events were anemia (8.3\%), nausea-vomiting (3.8\%) and diarrhea (1.8\%). In terms of efficacy, toxicity and convenience, cisplatin and capecitabine combination is effective and well tolerated in Turkish patients with advanced gastric cancer, and could be one of the standard regimens for the first-line treatment in this cohort.
\end{abstract}

Keywords: Advanced gastric cancer, Cisplatin, Capecitabine, Efficacy, Toxicity 
International Journal of Hematology and Oncology

ÖZET

İleri Evre Mide Kanserli Hastaların Birinci Basamak Tedavisinde Cisplatin ve Kapesitabin Kombinasyonunun Etkinlik ve Toksisitesi: Çok Merkezli Anadolu Tıbbi Onkoloji Derneği Çalışması

Mide kanseri tüm dünyada kanser tanısı alan hastaların \%10'undan, kanser ölümlerinin ise \%12 sinden sorumlu olan önemli bir sağlık problemidir. Hasta popülasyonları ve kullanılan tedavi protokollerinin farkllık göstermesi nedeniyle ileri evre mide kanseri tedavisinde standartlar halen oturmamıştır. Bu çalışma da ileri evre mide kanserli hastalarda sisplatin + kapesitabin kemoterapi kombinasyonunun birinci basamaktaki etkinliği araştııımıştır. Şubat 2006 - Aralık 2009 ylları arasında histopatolojik olarak konfirme edilmiş mide kanseri tanıs alan ve birinci basamakta cisplatin + kapesitabin kemoterapi kombinasyonu ile tedavi edilen hastaların verileri retrospektif olarak tarandı. Çalışmaya 11 farklı merkezden, 76 erkek ve 37 kadın hasta dahil edildi. Daha önce kemoterapi tedavisi uygulanan hastalar çalışmadan dışlandı. Hastaların ortalama yaşı 64 (aralık, 28-83) idi. Hastaların 76 (\%67.2)'sı erkek, 37 (\%32.7)'si kadındı. 85 (\%75.2) hasta tanı anında metastatikti. En sık rastlanılan metastaz bölgeleri sırasıyla karaciğer (\%65.9), akciğer (\%11.3), periton (\%23.8), lokal nüksler (\%15.9) ve çoklu bölge metastazı (\%9.7) idi. Hastaların ortalama takip süresi 41 ay (aralık, 12-61) idi. Hastalık kontrol oranları (DCR) \%72.6 iken tüm yanıt oranları (ORR) \%33.6 olarak bulundu. Ortanca progresyonsuz sağkalım 4.7 ay (95\%Cl 3.75-6.49) ve ortanca genel sağkalım 11.1 ay (95\% 5.58-10.98) idi. En sık bildirilen grade 3-4 yan etkiler anemi (\%8.3), bulantı-kusma (\%3.8) ve ishal (\%1.8) idi. Etkinlik, tolerabilite ve hasta uyumu açısından değerlendirildiğinde cisplatin + kapesitabin kemoterapi kombinasyonu ileri evre mide kanserli hastalarda tolere edilebilir ve etkin bir tedavi seçeneği olarak görünmektedir.

Anahtar Kelimeler: Ileri evre mide kanseri, Cisplatin, Kapesitabin, Etkinlik, Toksisite

\section{INTRODUCTION}

Gastric cancer (GC) is one of the leading causes of cancer related-deaths worldwide. ${ }^{1}$ Although the incidence and mortality of GC have been decreasing in the Western world, it is still one of the most common causes of cancer-related deaths. ${ }^{2,3}$ Its frequency varies among different countries and continents, being more prevalent in Eastern Asia and Southern America than Western Europe and Northern America. In Turkey, it is the 5th most common cancer in males and 6th most common cancer in females. About 8000 patients are newly diagnosed with GC annually. ${ }^{4}$

Overall prognosis of metastatic GC remains dismal. Overall response rates (ORR) with monotherapy are around $10-30 \% .{ }^{5}$ Although diversity of treatment options for metastatic GC have been increasing in the recent years with introduction of targeted agents, especially against Her2 oncogene, ${ }^{6,7}$ therapeutic options are limited for patients unsuitable for biologic agents. New generation cytotoxic agents such as paclitaxel, docetaxel, irinotecan and oxaliplatin have been used with minimal improvements in overall survival (OS). Use of triplet combinations has resulted in better survival outcomes with the cost of increasing toxicity. ${ }^{8-11}$ Despite prolonged survival with systemic chemotherapy, optimum combination regimes and schedules still vary according to geographical locations and physician preferences. Cisplatin and capecitabine combination has been widely utilized and used as a control arm in randomized trials of North America origin.

Capecitabine is an oral fluoropyrimidine which shows anti-tumoral effect similar to that of continuous infusional 5-fluorouracil (5-FU)., ${ }^{2,12,13}$ ORR of $19-34 \%$ have been achieved in metastatic GC monotherapy. ${ }^{14-16}$ ORR has reached up to $55 \%$ in a phase II study in which it has been combined with cisplatin. ${ }^{17}$ Because of its oral use ease with reduced toxicity and lack of need for a central catheter, capecitabine is a more preferable agent than 5-FU in combination with cisplatin. ${ }^{18}$ REAL2 study also showed that capecitabine can also be used instead of 5-FU in triple-drug combinations. ${ }^{12}$ There is no consensus on the optimum schedule of combining drugs with platinum agents. In Turkey, modified schedules of triplet combinations are still widely used. ${ }^{9-11}$ There is a paradigm shift to cisplatin and capecitabine combination in recent years. However, there is no data on the clinical efficacy and toxicity of cisplatin and capecitabine combination in Turkish patients. Therefore, this study aimed to retrospectively evaluate the efficacy and toxicity of first-line cisplatin and capecitabine chemotherapy combination in Her2-negative or Her2-unknown patients with advanced GC. 


\section{PATIENTS and METHODS}

\section{Patients}

Medical records of 113 advanced GC patients treated with first-line cisplatin and capecitabine combination between February 2006 and December 2009 were retrospectively analyzed in 11 centers of Anatolian Society of Medical Oncology. Patients previously treated with chemotherapy were excluded from the analysis. All the patients had histologically confirmed advanced gastric adenocarcinoma, measurable disease, no previous history of chemotherapy and radiotherapy other than adjuvant and/or neoadjuvant treatment, available clinical data, Eastern Cooperative Oncology Group (ECOG) performance status (PS) of 0-2, and sufficient renal, hepatic and cardiac functions. Cancer registration data of patients' follow up period were obtained from other centers and survival data analysis was updated. The study was approved by the Gazi University Medical School Ethics Committee.

\section{Treatment}

Typical chemotherapy schedule included cisplatin $80 \mathrm{mg} / \mathrm{m}^{2}$ administered as a 2-hour infusion together with hyperhydration in the first day. Capecitabine $1000 \mathrm{mg} / \mathrm{m}^{2}$ was administered orally twice daily between the days 1 and 14 with a treatment holiday for 7 days. Chemotherapy regimen was repeated every 3 weeks until disease progression or unacceptable toxicity according to the discretion of attending physician. Toxicity was evaluated and graded according to National Cancer Institute Common Toxicity Criteria (NCI-CTCAE) version 3 and recorded retrospectively from chart review. All patients had standard supportive treatment with hydration and antiemetics per institutional guidelines usually including dexamethasone, aprepitant and 5-hydroxytryptamine type 3 receptor antagonists.

\section{Statistics}

Tumor response was re-evaluated retrospectively for each patient by using Response Evaluation Criteria in Solid Tumors (RECIST). ${ }^{19}$ Complete response (CR) was defined as disappearance of all targeted and non-targeted lesions, normalization of tumor markers and absence of newly formed lesions. Partial response (PR) was described as $\geq 30 \%$ reduction in the summation of longest diameters of targeted lesions measured initially, and stable disease (SD) as persistence of one or more than one non-targeted lesions without progression and/or maintenance of tumor marker levels above normal value and absence of newly formed lesions. Progression-free survival (PFS) was defined as the time period from the initiation of treatment until disease progression or death, whichever comes first. OS was accepted as the time period from the initiation of treatment until death or the date of last follow-up visit. Starting date of OS and PFS was accepted as the first day of chemotherapy. Statistical analyses were performed using the SPSS software version 15 and $\mathrm{R}$ software version 3.1.2. (SPSS, Chicago,IL,USA). PFS and OS probabilities were assessed by Kaplan-Meier methods and compared with log-rank test.

\section{RESULTS}

\section{Patients}

The data of 113 patients from 11 different centers were evaluated retrospectively. Patient characteristics are shown in Table 1. The median age of the patients was 64 years (range, 28-83). Seventy-six (67.2\%) patients were males and 37 (32.7\%) females. Most of the patients were metastatic $(\mathrm{n}=$ $85,75.2 \%)$ at the time of initial diagnosis. Signetring cell carcinoma subtype was detected in 18 (15.9\%) patients. The most common sites for metastasis were liver $(65.9 \%)$, lung $(11.3 \%)$, peritoneum $(23.8 \%)$ and local recurrence $(15.9 \%)$ with multiple metastases in $9.7 \%$ of the patients. Her2 was analyzed in $9(7.9 \%)$ patients and found to be negative.

\section{Treatment}

A total number of 496 courses of chemotherapy were applied. Median number of chemotherapy courses was 4 (range, 1-12). The most common cause for discontinuation of chemotherapy was disease progression. In general, cisplatin-based chemotherapy regimens were well tolerated. Thirty (26.5\%) patients completed 6 courses of cisplatin and capecitabine treatment, while $42(37.1 \%)$ patients could receive $\leq 3$ courses of chemotherapy. 


\begin{tabular}{|c|c|c|}
\hline Characteristic & $\begin{array}{l}\text { Patients } \\
\text { n (113) }\end{array}$ & $\%$ \\
\hline \multicolumn{3}{|l|}{ Age, years } \\
\hline Median & 64 & \\
\hline Range & $28-83$ & \\
\hline Males/females & $76 / 37$ & $67.3 / 32.7$ \\
\hline \multicolumn{3}{|l|}{ Stage at diagnosis } \\
\hline $1-3$ & 28 & 24.8 \\
\hline 4 & 85 & 75.2 \\
\hline \multicolumn{3}{|c|}{ Number of metastatic sites } \\
\hline 1 & 100 & 88.5 \\
\hline$\geq 2$ & 13 & 11.5 \\
\hline \multicolumn{3}{|l|}{ Site of metastasis } \\
\hline Liver & 58 & 65.9 \\
\hline Lung & 10 & 11.3 \\
\hline Peritoneum & 22 & 23.8 \\
\hline Bone & 5 & 5.6 \\
\hline \multicolumn{3}{|c|}{ ECOG performance score } \\
\hline 0 & 13 & 11.5 \\
\hline 1 & 64 & 56.6 \\
\hline 2 & 36 & 31.9 \\
\hline \multicolumn{3}{|l|}{ Her2 status } \\
\hline Negative & 9 & 7.9 \\
\hline Unknown & 104 & 82.1 \\
\hline \multicolumn{3}{|c|}{ Prior adjuvant and/or neoadjuvant therapy } \\
\hline Chemotherapy & 20 & 17.7 \\
\hline Radiotherapy & 20 & 17.7 \\
\hline
\end{tabular}

\section{Efficacy}

The median follow-up period of all patients was 41.4 months (range, 12-61) on the date of data analysis. At the time of analysis, $95(84.1 \%)$ patients were dead. Four $(3.5 \%)$ patients achieved CR, 34 $(30.1 \%)$ PR, 44 (38.9\%) SD and $31(27.4 \%)$ developed PD. ORR was $33.6 \%$, while disease control rate (DCR) was $72.6 \%$. Median PFS was 4.7 months (95\%CI 3.75-6.49) and median OS was 11.1 months (95\%CI 5.58-10.98) (Figure 1A and 1B). For all patients, 1-year and 2-year OS rates were $29.2 \%$ and $15 \%$, respectively.

\section{Toxicity}

In general, combination treatment was well tolerated. Adverse events are summarized in Table 2.

\begin{tabular}{|lll|}
\hline Table 2. Toxicity profile & & \\
\hline Adverse events & $\begin{array}{l}\text { Grade 1-2 } \\
\text { n (\%) }\end{array}$ & $\begin{array}{l}\text { Grade 3-4 } \\
\mathbf{n}(\%)\end{array}$ \\
\hline Neutropenia & $34(31.5)$ & $9(8.3)$ \\
Febrile neutropenia & - & $5(4.4)$ \\
Anemia & $72(66)$ & $9(8.3)$ \\
Thrombocytopenia & $21(19.4)$ & $1(0.9)$ \\
Nausea & $58(55.8)$ & $4(3.8)$ \\
Vomiting & $40(35.3)$ & $4(3.8)$ \\
Diarhea & $29(26.6)$ & $2(1.8)$ \\
Pneumonitis & - & $1(0.8)$ \\
Bleeding & - & $4(3.5)$ \\
\hline
\end{tabular}

The most common grade 3-4 hematological toxicity was anemia $(8.3 \%)$. During treatment period, $5(4.4 \%)$ patients developed febrile neutropenia. The most common non-hematological grade 3-4 adverse events were nausea-vomiting (3.8\%) and diarrhea $(1.8 \%)$. One patient developed non-neutropenic pneumonia and died during treatment. One additional patient had a sudden death while on treatment. In both of these patients, treatmentrelated death was probable and there were no signs of clinical progression. Gastrointestinal tract bleeding was detected in 4 patients, and 2 of those subsequently received palliative radiotherapy. In 2 patients, treatment was discontinued on the third course due to cisplatin-related nephrotoxicity. In $23(20.4 \%)$ patients, dose was reduced due to toxicity and doses were delayed in $28(24.8 \%)$ patients. In 1 patient, capecitabine was stopped on the third course due to treatment non-compliance and 5-fluorouracil treatment was commenced.

\section{DISCUSSION}

Advanced GC remains a deadly disease despite the recent developments in its diagnosis and treatment. ${ }^{20}$ Prognosis is usually dismal with palliative chemotherapy with a median OS of approximately 10-12 months. In our analysis, the median OS rate was 11.7 months and PFS was 4.7 months consist- 

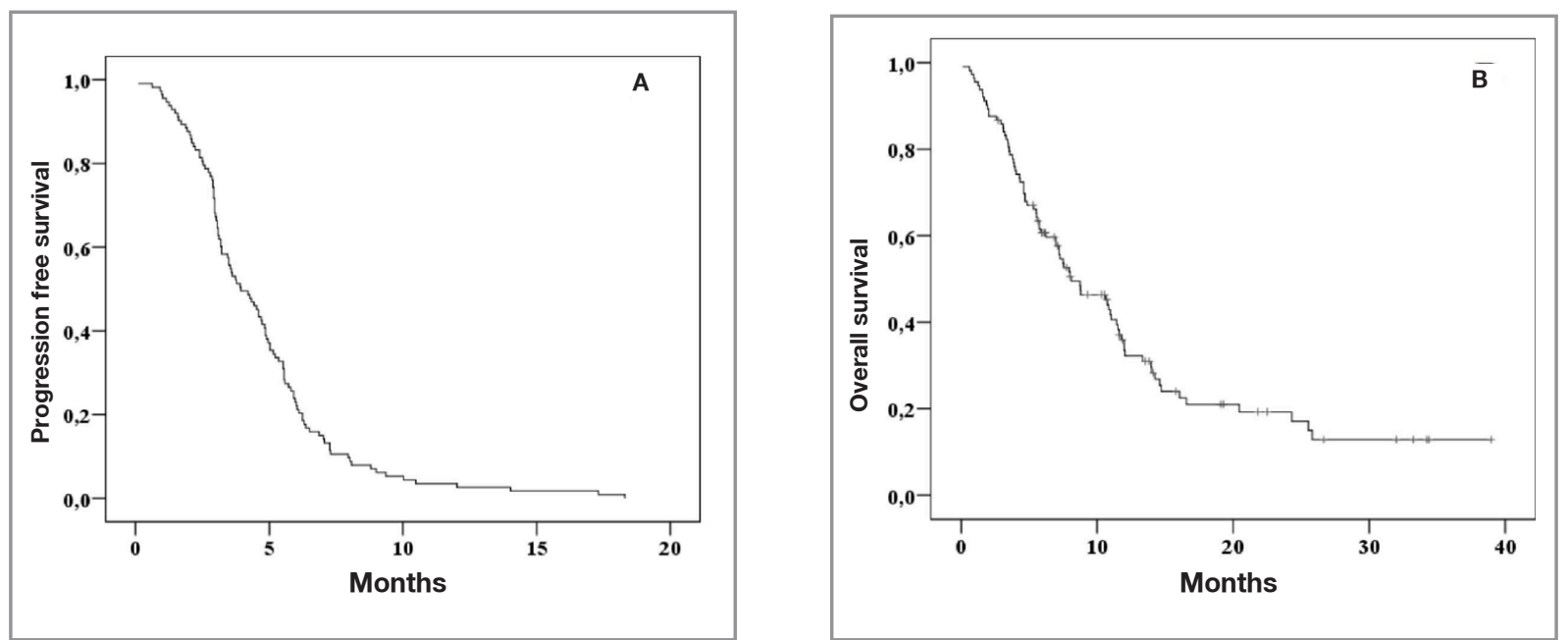

Figure 1. Kaplan-Meier curves for progression free survival and overall survival. A. Progression free survival. Median PFS was 4.7 months (95\% Cl 3.75- 6.49). B. Overall survival. Median OS was 11.1 months (95\% Cl 5.58- 11.98).

ent with literature data. Our results with conventional cisplatin-based chemotherapy are within the range of previously published studies in the literature. Our report confirms and extends previous reports demonstrating modest beneficial role of cisplatin-based doublets in the first-line treatment of advanced GC.

Systemic chemotherapy is the only treatment modality applied to improve survival, quality of life and symptom palliation in advanced stage GC. ${ }^{3,21}$ Although there are many studies intending to define optimal chemotherapy regimen, standard treatment modality is still debated and daily practice differs geographically. ${ }^{22}$ Response rates of cytotoxic monotherapies in phase II studies are $13-31 \%$ with short duration of response and limited impact on survival. Various phase II and III randomized studies have revealed that survival benefit of combination schedules was better than best supportive care and and single-agent chemotherapies., ${ }^{3,23-27}$

Doublet or triplet-drug cisplatin-based chemotherapy combinations are considered standard therapeutic regimens in the first-line treatment of metastatic GC. Platinum-containing combinations yield a significant survival advantage when compared to non-platinum schedules. ${ }^{20}$ Triplet combinations might have slightly improved efficacy, but this increased benefit is achieved at the cost of significant toxicity. ${ }^{8}$ Use of docetaxel, cisplatin and 5-FU resulted in a statistically significant, but numerically less than 1 month of survival benefit (9.2 months vs. 8.6 months). However, almost half of the patients could not complete the study due to toxicity. ${ }^{8}$ Therefore, whether triplet combinations are better than doublet cisplatin-based schedules are still debated.

The efficacy and safety of capecitabine have been directly evaluated in two phase III studies. ${ }^{28}$ Capecitabine is an oral fluoropyrimidine designed to mimic a continuous infusion of 5-FU. Capecitabine has shown good response rates in patients with AGC when given as monotherapy (19\%$34 \%)$ or in combination with cisplatin $(55 \%)$ in phase II studies. ${ }^{14-16}$ In recent years, oral fluoropyrimidines capecitabine and $\mathrm{S}-1$ have been used as single agents or in combinations instead of 5-FU in the treatment protocols containing 5 -FU. ${ }^{12,29} \mathrm{It}$ can easily be administered orally without a need for a permanent catheter with less toxicity. Daily oral dosage enables discontinuation of treatment in case of grade 3 or 4 toxicities and dose adjustments in necessary conditions throughout the cycle. For this reason, capecitabine combinations with cisplatin have become a globally accepted first-line chemotherapy regimen for patients with metastatic GC.

Cisplatin and capecitabine combination was welltolerated in our study. In terms of safety analysis, most of the treatment-related adverse events were grade 1-2 toxicities. Most frequent grade 3 and 4 
adverse events were anemia and neutropenia similar to the literature data. Four patients developed gastrointestinal bleeding and 2 of those required palliative radiotherapy for recurrent bleeding. As expected, grade 3 or 4 toxicities were less common when compared to triple-drug combinations. Retrospective character of the study and some missing toxicity records may contribute to limitations of our study in terms of adverse events recording.

In conclusion, when weighed in terms of efficacy, toxicity and convenience, cisplatin and capecitabine combination is an attractive choice among other cisplatin-based schedules. Since there are regional variations in the incidence, probable causative factors, surgical treatment and molecular profiles of GC, it is important to be cautious when making general interpretations of the results. While the identification of predictive markers and increased knowledge on disease biology improve clinical results with better patient selection, they may also guide in the development of personalized treatments for patients with advanced stage GC.

\section{REFERENCES}

1. Won YJ, Sung J, Jung KW, et al. Nationwide Cancer Incidence in Korea, 2003-2005. Cancer Res Treat 41: 122-131, 2009.

2. Kang YK, Kang WK, Shin DB, et al. Capecitabine/cisplatin versus 5-fluorouracil/ cisplatin as first-line therapy in patients with advanced gastric cancer: a randomised phase III noninferiority trial. Ann Oncol 20: 666-673, 2009.

3. Pyrhonen S, Kuitunen T, Nyandoto P, Kouri M. Randomised comparison of fluorouracil, epidoxorubicin and methotrexate (FEMTX) plus supportive care with supportive care alone in patients with non-resectable gastric cancer. $\mathrm{Br} J$ Cancer 71: 587-591, 1995.

4. http://www.turkcancer.org/dosyalar/istatistikler/turkiye-kanser-istatistikleri.pdf (Access date: 13.01.2016)

5. Pisters PWT, Kelsen DP, Tepper JE. Cancer of the Stomach. In: Cancer: Principles and Practice of Oncology. DeVita VT Jr, Hellman S, Rosenberg SA (eds). 8th edition. Wolters Kluwer Health and Lippincott Williams \& Wilkins, Philadelphia, 2008: 1043-1079.

6. Bang YJ, Van Cutsem E, Feyereislova A, et al. Trastuzumab in combination with chemotherapy versus chemotherapy alone for treatment of HER2-positive advanced gastric or gastrooesophageal junction cancer (ToGA): a phase 3, open-label, randomised controlled trial. Lancet 376: 687-697, 2010.

7. Baykara M, Benekli M, Ekinci $O$, et al. Clinical significance of HER2 overexpression in gastric and gastroesophageal junction cancers. J Gastrointest Surg 19: 1565-1571, 2015.

8. Van Cutsem E, Moiseyenko VM, Tjulandin S et al. Phase III study of docetaxel and cisplatin plus fluorouracil compared with cisplatin and fluorouracil as first line therapy for advanced gastric cancer: a report of the V325 study group. J Clin Oncol 24: 4991-4997, 2006.

9. Inal A, Kaplan MA, Kucukoner M, Isikdogan A. Docetaxel and cisplatin plus fluorouracil compared with modified docetaxel, cisplatin, and 5-fluorouracil as first-line therapy for advanced gastric cancer: a retrospective analysis of single institution. Neoplasma 59: 233-236, 2012.

10. Kos FT, Uncu D, Ozdemir N, et al. Comparison of cisplatin-5 fluorouracil-folinic acid versus modified docetaxel-cisplatin5 -fluorouracil regimens in the first-line treatment of metastatic gastric cancer. Chemotherapy 57: 230-235, 2011.

11. Alici S, Buyukberber S, Alkis N, et al. Anatolian Society of Medical Oncology. Low-dose docetaxel/cisplatin-leucovorin and 46-hour infusional fluorouracil in metastatic gastric carcinoma. Asian Pac J Cancer Prev 14: 423-427, 2013.

12. Cunningham D, Starling N, Rao S, et al. Capecitabine and oxaliplatin for advanced esophagogastric cancer. N Engl J Med 358: 36-46, 2008.

13. Koizumi W, Narahara H, Hara T, et al. S-1 plus cisplatin versus S-1 alone for first-line treatment of advanced gastric cancer (SPIRITS trial): a phase III trial. Lancet Oncol 9: 215-221, 2008.

14. Koizumi W, Saigenji K, Ujiie S, et al. A pilot phase II study of capecitabine in advanced or recurrent gastric cancer. Oncology 64: 232-236, 2003.

15. Sakamoto J, Chin K, Kondo K, et al. Phase II study of a 4-week capecitabine regimen in advanced or recurrent gastric cancer. Anticancer Drugs 17: 231-236, 2006.

16. Leon-Rodriguez E, Green D, Candelaria M, et al. Oral capecitabine in the treatment of patients with advanced or metastatic gastric carcinoma [abstract]. Ann Oncol 191 (13 Suppl): 708P, 2003.

17. Kim TW, Kang YK, Ahn JH, et al. Phase II study of capecitabine plus cisplatin as first-line chemotherapy in advanced gastric cancer. Ann Oncol 13: 1893-1898, 2002.

18. Kim TW, Chang HM, Kang HJ, et al. Phase II study of capecitabine plus cisplatin as first-line chemotherapy in advanced biliary cancer. Ann Oncol 14: 1115-1120, 2003.

19. Therasse P, Arbuck SG, Eisenhauer EA, et al. New guidelines to evaluate the response to treatment in solid tumors. European Organization for Research and Treatment of Cancer, National Cancer Institute of the United States, National Cancer Institute of Canada. J Natl Cancer Inst 92: 205-216, 2000.

20. Wagner AD, Grothe W, Haerting J, et al. Chemotherapy in advanced gastric cancer: a systematic review and meta-analysis based on aggregate data. J Clin Oncol 24: 2903-2909, 2006.

21. Glimelius B, Ekstrom K, Hoffman K, et al. Randomized comparison between chemotherapy plus best supportive care with best supportive care in advanced gastric cancer. Ann Oncol 8: 163-168, 1997.

22. Cunningham D, Chua JY. East meets west in the treatment of gastric cancer. N Engl J Med 357: 1863-1865, 2007.

23. Scheithauer W, Kornek G, Hejna M et al. Palliative chemotherapy versus best supportive care in patients with metastatic gastric cancer: A randomized trial. Ann Hematol 73 (suppl 2): A181, 1994. 
24. Murad AM, Santiago FF, Petroianu A, et al. Modified therapy with 5-fluorouracil, doxorubicin, and methotrexate in advanced gastric cancer. Cancer 72: 37-41, 1993.

25. Loehrer PJ Sr, Harry D, Chlebowski RT. 5-Fluorouracil vs. epirubicin vs. 5-fluorouracil plus epirubicin in advanced gastric carcinoma. Invest New Drugs 12: 57-63, 1994.

26. Cullinan SA, Moertel CG, Wieland HS, et al. Controlled evaluation of three drug combination regimens versus fluorouracil alone for the therapy of advanced gastric cancer: North Central Cancer Treatment Group. J Clin Oncol 12: 412-416, 1994.

27. Bouché $\mathrm{O}$, Raoul JL, Bonnetain F, et al. Randomized multicenter phase II trial of a biweekly regimen of fluorouracil and leucovorin (LV5FU2), LV5FU2 plus cisplatin, or LV5FU2 plus irinotecan in patients with previously untreated metastatic gastric cancer: A Fédération Francophone de Cancérologie Digestive Group study - FFCD 9803. J Clin Oncol 22: 43194328, 2004.

28. Okines AF, Norman AR, McCloud P, Kang YK, Cunningham D. Meta-analysis of the REAL-2 and ML17032 trials: evaluating capecitabine-based combination chemotherapy and infused 5-fluorouracil-based combination chemotherapy for the treatment of advanced oesophago-gastric cancer. Ann Oncol 20: 1529-1534, 2009.

29. Koizumi W, Narahara H, Hara T, et al. S-1 plus cisplatin versus S-1 alone for first-line treatment of advanced gastric cancer (SPIRITS trial): a phase III trial. Lancet Oncol 9: 215-221, 2008.

\section{Correspondence}

\section{Dr. Mustafa BENEKLI}

Gazi Üniversitesi Tip Fakültesi

Tibbi Onkoloji Bilim Dali

Besevler, ANKARA / TURKEY

Tel: (+90-312) 2025834

Fax: (+90-312) 2158710

E-mail: mbenekli@gmail.com 